\title{
Physical therapy treatment in the functional recovery of dogs submitted to head and femoral neck ostectomy: 20 cases
}

\author{
Ana Caroline Teixeira Colvero ${ }^{1}$ (i) Marcelo Luís Schwab ${ }^{1}$ (i) Dênis Antonio Ferrarin ${ }^{1}$ (i) \\ Angel Ripplinger ${ }^{1}$ Lícia Flávia Silva Herculano ${ }^{1}$ Mathias Reginatto Wrzesinski ${ }^{1}$ (i) \\ Júlia da Silva Rauber $^{1}$ (i) Alexandre Mazzanti $^{i^{* *}}$
}

${ }^{1}$ Programa de Pós-graduação em Medicina Veterinária, Serviço de Fisioterapia Veterinária (Fisiovet), Hospital Veterinário Universitário (HVU), Centro de Ciências Rurais (CCR), Universidade Federal de Santa Maria (UFSM), Santa Maria, RS, Brasil.

${ }^{2}$ Departamento de Clínica de Pequenos Animais, Serviço de Fisioterapia Veterinária (Fisiovet), Centro de Ciências Rurais (CCR), Hospital Veterinário Universitário (HVU), Universidade Federal de Santa Maria (UFSM), 97105-900, RS, Brasil. E-mail: alexamazza@yahoo.com.br. "Corresponding author.

ABSTRACT: Patients who undergo excisional surgical procedures such as femoral head and neck ostectomy (FHO) require a postoperative rehabilitation plan which includes different physical therapy modalities. Therefore, this retrospective study was done to demonstrate the different physical therapy modalities utilized in 20 dogs who were subjected to FHO, and to provide data on the frequency of physical therapy modalities, the protocol duration and time interval from the commencement of physiotherapy and surgery and the patient's functional recovery. All the protocols included the modalities of thermotherapy (heat), massage, passive stretching and passivejoint movement. In the initial phase, electrotherapy and therapeutic ultrasound were most often used, while the water treadmill was continued until the treatment was completed. Physiotherapy sessions varied from 3 to 50 in number, and physiotherapy was commenced from day 5 until day 214 post the surgical procedure. The functional recovery of the limb was in the following range: $65 \%$ (13/20) satisfactory, 25\% (5/20) partially satisfactory and 10\% (2/20) unsatisfactory. Physical therapy treatment was thus concluded to be most influential in the functional recovery of the limb, even if was started late.

Key words: veterinary physiotherapy, physical therapy protocol, orthopedics, surgery, neurology.

Tratamento fisioterapêutico na recuperação funcional de cães submetidos à ostectomia da cabeça e colo femoral: 20 casos

RESUMO: Um plano de reabilitação no pós-operatório incluindo diferentes modalidades fisioterapêuticas é de suma importância em pacientes submetidos à procedimentos cirúrgicos excisionais como a ostectomia da cabeça e colo femoral (OCCF). Sendo assim, o objetivo desse estudo retrospectivo foi demonstrar as diferentes modalidades fisioterapêuticas empregadas nos 20 cães após OCCF e fornecer dados referentes à frequência das modalidades fisioterapêuticas, a duração dos protocolos e o tempo entre o início da fisioterapia e a cirurgia e a recuperação funcional do paciente. A termoterapia (calor), a massagem, o alongamento passivo e a movimentação passiva articular foram as modalidades empregadas em todos os protocolos. A eletroterapia e o ultrassom terapêtico foram as mais utilizadas na fase inicial e, a esteira aquática foi mantida até o final do tratamento. O número de sessões de fisioterapia variou de 3 a 50 e o início da fisioterapia de 5 a 214 dias após o procedimento cirúrgico. Quanto à recuperação funcional do membro, em $65 \%(13 / 20)$ foram satisfatórias, em $25 \%$ (5/20) parcialmente satisfatórias e em 10\% (2/20) insatisfatórias. Pode-se concluir que o tratamento fisioterapêutico influenciou na recuperação funcional do membro, mesmo que iniciado tardiamente.

Palavras-chave: fisioterapia veterinária, protocolo fisioterapêtico, ortopedia, cirurgia, neurologia.

\section{INTRODUCTION}

In veterinary medicine, surgeons continue to be hesitant to include physiotherapy exercises post an orthopedic surgical procedure. However, an appropriate rehabilitation plan adopted during the postoperative period, which includes different physical therapy modalities, will definitely provide a higher degree of patient comfort and a speedier return of limb function (DAVIDSON et al., 2005).

The goal of femoral head and neck ostectomy (FHO) was to eliminate joint and bone contact and relieve the pain (HARPER, 2017), and it is indicated in the treatment of a variety of diseases of the hip joint 
(ACF) (VINAYAK et al., 2006). After employing this excisional technique, it is necessary to encourage the early use of the limb, to avoid excessive periarticular fibrosis and limitations in movement (DAVIDSON et al., 2005).

Although, in recent years, the adoption of physiotherapy modalities in small animals is a fastgrowing trend, even so, there is a paucity of scientific articles which demonstrate the inclusion of physical therapy during the postoperative period of dogs which undergo orthopedic surgeries.

Therefore, the present retrospective study was performed with the aim to demonstrate the different physical therapy modalities used in 20 dogs, post FHO, and providing data on the physical therapy modality frequency, protocol duration and the time interval from the commencement of the physiotherapy and surgery to functional recovery of the patient.

\section{MATERIALS AND METHODS}

This retrospective study included 20 dogs who experienced FHO and attended the physiotherapy sector of a higher education institution. These patients had a clinical record of the complete data including age, sex, race, body weight, clinical diagnosis for indication of FHO, frequency and number of physiotherapy sessions, commencement of physiotherapy post surgery, physical therapy modalities and functional recovery of the limb. The physiotherapeutic modalities used in the protocols of these dogs were included based on the postoperative evolution and functional recovery, as evident in tables 1, 2 and 3.

Each physical therapy modality type was employed following the recommendations in the literature, including cryotherapy (HANKS et al., 2015), massage (DRUM, 2010), neuromuscular electrical stimulation (NMES) (Figure 1A) (PELIZZARI et al., 2008), superficial thermotherapy (hot water shower) (DRAGONE et al., 2014) and therapeutic ultrasound (US) continuous mode, with $3 \mathrm{MHZ}$ frequency and intensities ranging from $0.3 \mathrm{~W} / \mathrm{cm}^{2}$ to $1 \mathrm{~W} / \mathrm{cm}^{2}$ (Figure 1B) (HANKS et al., 2015); passive stretching and passive joint

Table 1 - Representation in terms of race, age, sex, weight, surgical indication and physiotherapeutic modalities used to rehabilitate 20 dogs submitted to femoral head and neck ostectomy.

\begin{tabular}{|c|c|c|c|c|}
\hline $\operatorname{Dog}\left(n^{0}\right)$ & Race, Age (years) & Sex, Weight (kg) & Indication of FHO & Physical Therapy Modality \\
\hline 1 & Mixed-breed,2 & $\mathrm{F}, 10,7$ & Right hip luxation & US/M/PS/MPA/NMES/STW/O/MW \\
\hline 2 & Boxer,4 & $\mathrm{F}, 30$ & Right hip dysplasia & US/M/PS/MPA/NMES/GW \\
\hline 3 & Mixed-breed,14 & $\mathrm{F}, 2,7$ & Acetabulum fracture & US/M/PS/MPA/NMES/H \\
\hline 4 & Poodle, 7 & $\mathrm{~F}, 11,2$ & Right hip luxation & $\mathrm{Cr} / \mathrm{US} / \mathrm{M} / \mathrm{PS} / \mathrm{MPA} / \mathrm{NMES} / \mathrm{O} / \mathrm{H}$ \\
\hline 5 & Collie, 11 & $\mathrm{~F}, 22$ & Right hip luxation & US/M/PS/MPA/NMES/H \\
\hline 6 & Border,1 & $\mathrm{F}, 13$ & Left hip luxation & US/M/PS/MPA/NMES/O/MW/SS/PP/H \\
\hline 7 & Golden,5 & $\mathrm{M}, 34$ & Left hip luxation & US/M/PS/MPA/STW/O/MW/H \\
\hline 8 & Mixed-breed,1 & $\mathrm{M}, 22,5$ & Left hip luxation & US/M/PS/MPA/NMES \\
\hline 9 & Poodle, 11 & $\mathrm{~F}, 5,8$ & Right hip luxation & US/M/PS/MPA/NMES/O/H \\
\hline 10 & Cocker, 12 & $\mathrm{~F}, 15$ & Right hip luxation & HWS/M/PS/MPA/NMES/B/H \\
\hline 11 & Poodle, 7 & $\mathrm{~F}, 4,6$ & Bilateral hip luxation & US/M/PS/MPA/NMES/O/MW/GW/PP/H \\
\hline 12 & Pug, 5 & $\mathrm{~F}, 9,4$ & Bilateral ANFH & US/M/PS/MPA/NMES/PP \\
\hline 13 & Spitz,5 & $\mathrm{M}, 6,7$ & Bilateral ANFH & US/M/PS/MPA/NMES/PP/STW/O/MW/D/B \\
\hline 14 & Pequinês, 1 & $\mathrm{~F}, 4,5$ & Right ANFH & $\mathrm{Cr} / \mathrm{US} / \mathrm{M} / \mathrm{PS} / \mathrm{MPA} / \mathrm{STW} / \mathrm{O} / \mathrm{MW} / \mathrm{PP} / \mathrm{H}$ \\
\hline 15 & Mixed-breed,1 & $\mathrm{M}, 3,4$ & Right ANFH & US/M/PS/MPA/NMES/PP/O/TW/H \\
\hline 16 & Yorkshire, 1 & $\mathrm{~F}, 2,5$ & Left ANFH & US/M/PS/MPA/NMES/GW/H \\
\hline 17 & Shetland, 1 & $\mathrm{~F}, 6$ & Right hip luxation & US/M/PS/MPA/NMES/O/MW/PP/H \\
\hline 18 & Mixed-breed,1 & $\mathrm{M}, 6,8$ & Right hip dysplasia & US/M/PS/MPA/NMES/PP/O/MW/TW/H \\
\hline 19 & Poodle, 8 & $\mathrm{~F}, 3,5$ & Left hip luxation & $\mathrm{Cr} / \mathrm{HWS} / \mathrm{M} / \mathrm{PS} / \mathrm{MPA} / \mathrm{NMES} / \mathrm{O} / \mathrm{GW} / \mathrm{H}$ \\
\hline 20 & Boxer,6 & $\mathrm{F}, 35$ & Left hip dysplasia & $\mathrm{Cr} / \mathrm{US} / \mathrm{M} / \mathrm{PS} / \mathrm{MPA} / \mathrm{NMES} / \mathrm{O} / \mathrm{SS} / \mathrm{H}$ \\
\hline
\end{tabular}

FHO: Femoral Head and Neck Ostectomy; M: Male. F: Female; ANFH: Asseptic Necrosis Femoral Head;US: Ultrasound; M: Massage; PS: Passive Stretching; MPA: Passive Joint Movement; HWS: Hot Water Shower; NMES: Neuromuscular Electrical Stimulation; STW: Soil Types Walk; O: Obstacle; MW: Matress Walk; H: Hydroterapy (water mat); TW: Tunnel Walk; GW: Guided Walk; Cr: Cryotherapy; SS: Sit-and-Stand; PP: Proprioceptive Platform. D: Dance; B: Ball. 
movement (MPA) exercises (MARCELLIN-LITTLE \& LEVINE, 2015); active-assisted exercises like the circular proprioceptive platform (HAMILTON et al., 2004), ball exercises (EVANS et al., 2013) and dance (MARCELLIN-LITTLE \& LEVINE, 2015) and active exercises such as water mat (hydrotherapy) (Figure 1C) (DRUM et al., 2015), circuit-shaped walks having different soil types, guided walk, mattress, obstacles (Figure 1D), tunnel and repeated sit-and-stand exercises (DOYLE, 2004).

Regarding functional recovery, results were considered satisfactory when the limb was provided with constant support on the ground; partially satisfactory, when intermittent support was present or lameness was observed, and unsatisfactory when no support to the limb was observed (elevated limb) during the walk.

Regarding races, 5 dogs $(25 \%)$ had no defined race (SRD) and 15 (75\%) were purebred. Age was in the range of 1 to 14 years, with 5 years being the average age. In terms of gender, 14 were females (five castrated) and six were male (three castrated). Body weight ranged from 2.5 to $35 \mathrm{~kg}$ (Table 1).

The statistical analysis was processed using the ActionStat program, with the Chi-square parametric test $(\chi 2)$ to identify the relationship between the functional recovery and number of sessions and time when physiotherapy was commenced post surgery, with the level of significance considered being $\mathrm{p}<0.05$. In the analysis, the sessions and time of commencement of physiotherapy were separated into groups of 3 to 10,11 to 20 and beyond 20 sessions and days, respectively.

\section{RESULTS AND DISCUSSION}

The physiotherapeutic modalities employed are taken from the current literature on veterinary physiotherapy (MILIS \& LEVINE, 2014; PRYDIE \& HEWIT, 2015; MCGOWAN \& GOFF, 2016), adopting the guidelines established for the use of each modality, in accordance with the surgical technique and duration post the operative procedure (PRYDIE \& HEWIT, 2015). This study; however, also attempted to provide results that are scarce in the articles, at both national and international levels.

In patients who undergo FHO, the rehabilitation must, of necessity, be started within 48 hours post the procedure (DYCUS et al., 2017); however, this was not done for any of the dogs in this study, as seen in table 3, where it is observed that the commencement of rehabilitation after

Table 2 - Representation of the number of sessions and functional recovery of the 20 dogs submitted to femoral head and neck ostectomy.

\begin{tabular}{|c|c|c|}
\hline $\operatorname{Dog}\left(n^{0}\right)$ & Number of sessions & Functional recovery \\
\hline 1 & 6 & Partially satisfactory \\
\hline 2 & 15 & Partially satisfactory \\
\hline 3 & 8 & Satisfactory \\
\hline 4 & 5 & Satisfactory \\
\hline 5 & 18 & Poor \\
\hline 6 & 45 & Satisfactory \\
\hline 7 & 6 & Satisfactory \\
\hline 8 & 3 & Partially satisfactory \\
\hline 9 & 7 & Satisfactory \\
\hline 10 & 16 & Poor \\
\hline 11 & 10 & Satisfactory \\
\hline 12 & 13 & Satisfactory \\
\hline 13 & 8 & Satisfactory \\
\hline 14 & 15 & Satisfactory \\
\hline 15 & 15 & Satisfactory \\
\hline 16 & 11 & Partially satisfactory \\
\hline 17 & 50 & Partially satisfactory \\
\hline 18 & 26 & Satisfactory \\
\hline 19 & 15 & Satisfactory \\
\hline 20 & 18 & Satisfactory \\
\hline
\end{tabular}

Ciência Rural, v.50, n.11, 2020. 
surgery occurred anytime from 5 to 214 days. This result enabled us to suggest that physical therapy was indicated only when no spontaneous functional recovery of the affected pelvic limb was observed, because all the dogs referred to physiotherapy did not support the limb.

Even late and, contrary to the recommendation of DYCUS et al. (2017) physiotherapy facilitated functional recovery in the dogs, in most cases, in this study (Table 3); however, no relationship was noted between when the physiotherapy was commenced and functional recovery. Thus, it is evident that the physical therapy treatment employed in the dogs post FHO affected the satisfactory clinical recovery, irrespective of exactly when it was started during the postoperative period. However, a greater number of animals need to be studied to offer proof for these results.

Conversely, and despite the results cited above, early physical therapy is indicated in animals that experience FHO because it permits modulation of the periarticular fibrous tissue induced by the healing process. This is one of the causes for the limitation and pain during movement, making it one of the principal complications in this surgery (HARPER, 2017). The authors of this study reiterate that physiotherapy should not be regarded as the final therapeutic option, but as an adjunct to patient recovery, and which should be commenced at the earliest.

In this study, the sessions ranged from 3 to 50 in number which, on average, for those dogs that revealed satisfactory and partial satisfactory recovery was 13 and 17, respectively (Table 2). The data drawn from the relationship between the number of sessions and functional recovery revealed no significant difference. One plausible explanation for this variation in the number of sessions, in this study, can be attributed to the satisfaction of the tutors with the recovery and / or the cancellation of the physical therapy treatment. This fact was observed in $80 \%$ of the cases of the dogs which showed partial satisfactory recovery. In fact, ANDRADES et al. (2018) reported a $40 \%$ rate of interruption of the physiotherapy treatment and stated other reasons, such as the expense and difficulty for the tutors to travel to the physiotherapy center, something that possibly actually happened in this study.

The average time taken from the commencement to the end of the physiotherapy treatment of the dogs in this study was $\mathbf{5 4}$ days. In their study on dogs who were subjected to FHO and transacetabular pin insertion, BARBOSA et al. (2012) recorded

Table 3 - Representation of the commencement of physiotherapy post surgery and the functional recovery of the 20 dogs submitted to femoral head and neck ostectomy.

\begin{tabular}{|c|c|c|}
\hline $\operatorname{Dog}\left(n^{\circ}\right)$ & Physiotherapy commenced after surgery (days) & Functional recovery \\
\hline 1 & 13 & Partially satisfactory \\
\hline 2 & 214 & Partially satisfactory \\
\hline 3 & 29 & Satisfactory \\
\hline 4 & 11 & Satisfactory \\
\hline 5 & 15 & Poor \\
\hline 6 & 5 & Satisfactory \\
\hline 7 & 33 & Satisfactory \\
\hline 8 & 12 & Partially satisfactory \\
\hline 9 & 7 & Satisfactory \\
\hline 10 & 16 & Poor \\
\hline 11 & 11 & Satisfactory \\
\hline 12 & 12 & Satisfactory \\
\hline 13 & 10 & Satisfactory \\
\hline 14 & 28 & Satisfactory \\
\hline 15 & 30 & Satisfactory \\
\hline 16 & 5 & Partially satisfactory \\
\hline 17 & 59 & Partially satisfactory \\
\hline 18 & 16 & Satisfactory \\
\hline 19 & 5 & Satisfactory \\
\hline 20 & 5 & Satisfactory \\
\hline
\end{tabular}

Ciência Rural, v.50, n.11, 2020. 
satisfactory recovery without physiotherapy, after 1296 days, on average. Therefore, the significance of physical therapy during the early recovery of the limb in the postoperative period is evident.

Regarding physical therapy modalities, the tutors used cryotherapy in $19 \%$ of cases $(n=4)$. The action potential of ice minimizes the signs of inflammation, as ice is an important analgesic agent, particularly during the acute tissue damage phase (up to 72 hours) (MILLIS \& CIUPERCA, 2015). In this study, the plausible explanation for the 16 remaining dogs not been given this modality was because the surgeon failed to prescribe it during the immediate postoperative period or the late commencement of the physiotherapy sessions, at 72 hours post the surgical procedure.

Thermotherapy which involves continuous therapeutic ultrasound (Figure 1B) and hot water showers were employed in $90 \%$ and $10 \%$ of the protocols, respectively (Table 1). The objective was to induce local warming (thermal effect) and increase the tissue extensibility and blood circulation and thus relieve pain, as well as promote the effectiveness of stretching and MPA and joint amplitude gain (DAVIDSON et al., 2005; MILLIS \& CIUPERCA, 2015; HANKS et al., 2015).

Following and post the completion of the ultrasound or hot water shower, all the animals were given a massage, stretching and MPA. The massage was recommended for muscle tension relief, because it interrupts the self-perpetuation of the spasm-painspasm cycle (SUTTON \& WHITLOCK, 2014), and is also a good way to warm up the muscles prior to exercise (DRUM, 2010). Stretching and MPA are prescribed to ameliorate joint flexibility, extensibility of periarticular tissues and muscle elasticity (SOUZA et al., 2006), thus improving the range of motion and aiding in maintaining the joint health (MARCELLINLITTLE \& LEVINE, 2015).

The NMES (Russian stimulation) encourages muscle contraction, limits atrophy and muscle strength loss induced by disuse, besides raising the blood

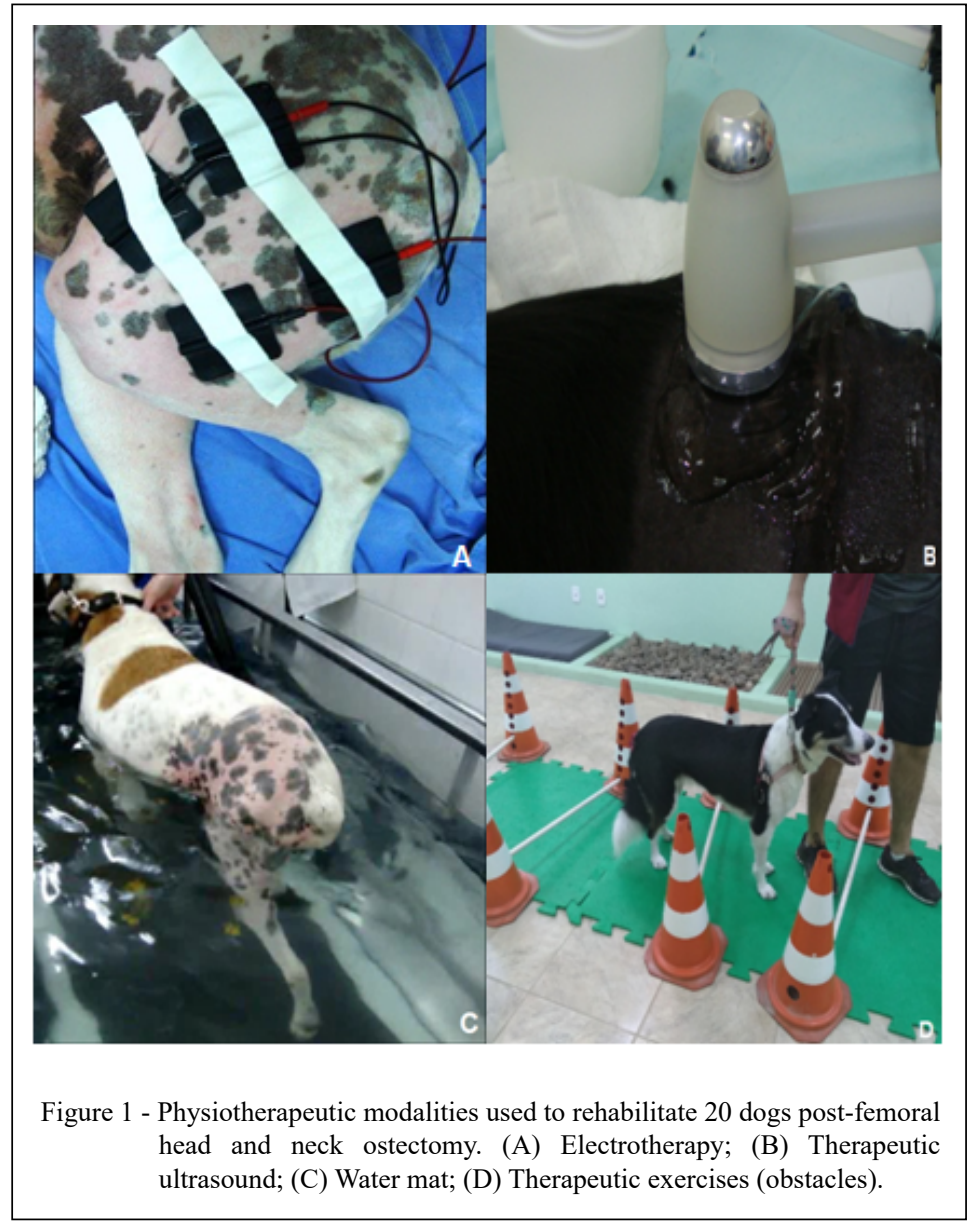

Ciência Rural, v.50, n.11, 2020. 
supply for tissue healing (DOYLE, 2004; EVANS et al., 2013). For these reasons, in $90 \%$ of the protocols, electrical stimulation was used (Figure 1A) until the animals were able to support the limb on the ground, even partially, at least (Table 1).

Among the assisted exercises the animals were subjected to, the proprioceptive platform and ball exercises were done with the intention of encouraging the early use of the limb and provoke muscle contraction (EVANS et al., 2013; MILLIS \& LEVINE, 2014). The aim of the dance exercise was also to stimulate muscle strengthening, but with maximum hip extension (DAVIDSON et al., 2005). While these modalities were used in $45 \%$ of the protocols, the platform was used in $40 \%$ of the cases.

Active exercises done in the water, either on an aquatic mat or through swimming, induce support for the limbs much sooner than through exercise performed on dry soil (SIMS et al., 2015). Some of the principal advantages of the water treadmill include raised cardiovascular fitness, greater joint mobility and improved muscle strength and endurance (MONK, 2016). In fact, as 75\% of the patients (Figure 1C) subjected to this modality experienced benefits, it was maintained until the protocol was completed. Although, swimming is a good conditioning exercise, it does not encourage the extension of the hip joint which is recommended in patients post FHO (DAVIDSON et al., 2005). It was; therefore, used in only $20 \%$ of the patients.

Other therapeutic exercises adjuvant to the treatment that have been implemented from the commencement to the completion of the protocols include walking, with a guide, on a proprioceptive track, on a mattress, with obstacles (Figure 1D), through a tunnel, and sit-and-stand exercises. The aim was to improve the endurance, muscle strength, joint mobility and the use of the limbs (MILLIS \& LEVINE, 2014), which are employed in $85 \%$ of the cases.

In $20 \%$ of the protocols, walking on a proprioceptive trail was included; in $40 \%$, walking on a mattress; in $20 \%$, a guide was added; in $65 \%$, obstacles were used; in $10 \%$, tunneling was incorporated and in $10 \%$ sit-and-stand exercises were included (Table 1). Several of these modalities were either incorporated or changed, based on the acceptance / adaptation of the animals, and on which exercise provided the most positive outcomes for the patient. For the sit-andstand exercise the animal requires training to properly perform it (DRUM et al., 2015). This is the reason for the low adherence, by this modality, in this study. In terms of functional recovery, in 13 dogs $(65 \%)$ it was accepted as satisfactory, in 5 dogs $(25 \%)$ it was considered partially satisfactory and in two $\operatorname{dogs}(10 \%)$ it was unsatisfactory. The main reason for the failure to achieve postoperative recovery is the permanence of the bone in the femoral neck caused by inadequate excision, which induces pain and interrupts the occurrence of pseudarthrosis, as demonstrated by OBER et al. (2018).

In this study, this complication was evident in $85 \%(3 / 5)$ of the dogs, which showed partial satisfactory recovery; and therefore, surgical reintervention was required (Table 2). Biomechanical changes cannot always produce normal gait and function, especially in cases where a functional shortening of the limb is present, and which can induce gait abnormalities (DAVIDSON et al., 2005). Besides, DRUM et al. (2015) and DYCUS et al. (2017) reported that the presence of co-morbidities, type of injury, adaptation by the patient and owner compliance are other factors that can affect recovery, a situation that was probably noted in the dogs with partially satisfactory and unsatisfactory recovery (Table 2).

Although, the main goal of this study was to show the way physical therapy influenced the functional recovery of the limb post FHO, some limitations that can be cited here includde the small number of dogs and the lack of a control group. Prospective studies that permit the standardization of different variables will be preferable, as the results will allow for more precise conclusions to be drawn regarding the important role played by physical therapy in recovery.

The relevance of this retrospective study was to reveal the different physical therapy modalities employed in the 20 dogs post FHO and provide data on the frequency of the physical therapy modalities, duration of the protocols and the time interval from the commencement of the physiotherapy and surgery to the functional recovery of the patient.

\section{CONCLUSION}

From the results obtained, the conclusions drawn were that thermotherapy, passive stretching and MPA were the modalities included in the protocol for all dogs. Electrotherapy and ultrasound were the most frequently used methods during the initial phase and the water mat was used right from the commencement to the completion of the treatment. Physiotherapy was noted to provide a satisfactory effect on the functional recovery of the limbs in the dogs submitted to FHO, even when started late in the treatment. 


\section{ACKNOWLEDGEMENTS}

This study was supported and financed by Conselho Nacional de Desenvolvimento Científico e Tecnológico (CNPq) process number 307120-2017-1 and was financed in part by the Coordenação de Aperfeiçoamento de Pessoal de Nível Superior (CAPES), Brasil - Finance code 001.

\section{DECLARATION OF CONFLICT OF} INTERESTS

The authors declare no conflict of interest. The founding sponsors had no role in the design of the study; in the collection, analyses, or interpretation of data; in the writing of the manuscript, and in the decision to publish the results.

\section{AUTHORS' CONTRIBUTIONS}

The authors contributed equally to the manuscript.

\section{REFERENCES}

ANDRADES, A. O. et al. Physiotherapeutic modalities in the rehabilitation of dogs with thoracolumbar intervertebral disc disease that underwent to decompressive surgery: 30 cases (20082016). Arquivo Brasileiro de Medicina Veterinária e Zootecnia, v.70, n.4, p.1089-1098, 2018. Available from: <https://www. scielo.br/pdf/abmvz/v70n4/1678-4162-abmvz-70-04-01089.pdf>. Accessed: Nov. 12, 2018. doi: 10.1590/1678-4162-9953.

BARBOSA, A. L. T. et al. Functional recovery of hip joint postoperative in dogs: clinic, radiographic and biomechanical study. Ciência Rural. vol.42, n.11, p.2011-2017, 2012. Available from: <https://www.scielo.br/pdf/cr/v42n11/a32912cr5200.pdf> Accessed: Aug. 12, 2018. doi: 10.1590/S0103-84782012005000099.

DAVIDSON, J. R. et al. Rehabilitation for the orthopedic patient. Veterinary Clinics of North America. Small Animal Practice, v.35, p.1357-1388, 2005. Available from: $<$ https://www.sciencedirect.com/science/article/abs/pii/ S0195561605001099?via\%3Dihub>. Accessed: May, 13, 2019. doi: 10.1016/j.cvsm.2005.08.006

DOYLE, N. D. Rehabilitation of fractures in small animals: maximize outcomes, minimize complications. Clinical Techniques in Small Animal Practice, v.19, p.180-191, 2004. Available from: <https://www.sciencedirect.com/science/article/ abs/pii/S109628670400060X>. Accessed: Jun. 12, 2018. doi: 10.1053/j.ctsap.2004.09.010.

DRAGONE, L. et al. Superficial thermal modalities. In: MILLIS, D.L.; LEVINE, D. 2. ed. Elsevier, 2014. Cap.18, p 312-327.

DRUM, M. G. et al. Principles and applications of therapeutic exercises for small animals. Veterinary Clinics of North America. Small Animal Practice, v.45, p.73-90, 2015. Available from: $<$ https://www.sciencedirect. com/science/article/abs/pii/S0195561614001375?via\%3Dihub>. Accessed: May, 5, 2019. doi: 10.1016/j.cvsm.2014.09.005.

DRUM, M. G. Physical rehabilitation of the canine neurologic patient. Veterinary Clinics of North America. Small Animal Practice, v.40, p.181-193, 2010. Available from: $<$ https://www.sciencedirect.com/science/article/abs/pii/
S0195561609001478?via\%3Dihub>. Accessed: May, 12, 2019. doi: 10.1016/j.cvsm.2009.09.009.

DYCUS, D. L. et al. Physical rehabilitation for the management of canine hip dysplasia. Veterinary Clinics of North America. Small Animal Practice, v.47. p.823-850, 2017. Available from: $<$ https://pubmed.ncbi.nlm.nih.gov/28576271/>. Accessed: May, 12, 2019. doi: 10.1016/j.cvsm.2017.02.006.

EVANS, W. G. et al. Fundamentals of physical rehabilitation. In: FOSSUM, T.W. Small animal surgery. 4.ed. St. Louis: Elsevier, 2013. Cap.11, p.114-130.

HAMILTON, S. et al. Therapeutic exercises. In: MILLIS, D.L.; LEVINE, D.; TAYLOR, R.A. Canine rehabilitation and physical therapy. Philadelphia: Saunders, 2004. p. 244-263.

HANKS, J. et al. Physical agent modalities in physical therapy and rehabilitation of small animals. Veterinary Clinics of North America. Small Animal Practice, v.45, p.29-44, 2015. Available from: <https://pubmed.ncbi.nlm.nih.gov/25432680/>. Accessed: May, 12, 2019. doi: 10.1016/j.cvsm.2014.09.002.

HARPER, T. A. M. Femoral head and neck excision. Veterinary Clinics of North America. Small Animal Practice, v.47, p.885-897, 2017. Available from: <https://pubmed.ncbi.nlm. nih.gov/28576273/>. Accessed: May, 11, 2019. doi: 10.1016/j. cvsm.2017.03.002.

LEVINE, D. Canine rehabilitation and physical therapy. 2ed. Philadelphia: Elsevier, 2014. Cap.28, p.484-494.

MCGOWAN, C. M; GOFF, L. Animal physiotherapy: assessment, treatment and rehabilitation of animals. Chichester: JohnWiley \& Sons. 2.ed. 2016. 369p.

MILLIS, D. L.; CIUPERCA. I. A. Evidence for canine rehabilitation and physical therapy. Veterinary Clinics of North America. Small Animal Practice, v.45, p.1-27, 2015. Available from: $<$ https://pubmed.ncbi.nlm.nih.gov/25432679/>. Accessed: May, 12, 2019. doi: 10.1016/j.cvsm.2014.09.001.

MARCELLIN-LITTLE, D. J.; LEVINE, D. Principles and application of range of motion and stretching in companion animals. Veterinary Clinics of North America. Small Animal Practice, v.45, p.57-72, 2015. Available from: <https://pubmed. ncbi.nlm.nih.gov/25440753/>. Accessed: May, 13, 2018. doi: 10.1016/j.cvsm.2014.09.004.

MONK, M. Aquatic therapy. In: MCGOWAN, C. M; GOFF, L. Animal physiotherapy: assessment, treatment and rehabilitation of animals. Chichester: JohnWiley \& Sons. 2.ed. Cap.14, p.225-237, 2016.

OBER, C. et al. Use of clinical and computed tomography findings to assess long-term unsatisfactory outcome after femoral head and neck ostectomy in four large breed dogs. Acta Veterinaria Scandinavica. v.60, n.28, p.1-5, 2018. Available from: <https://www.ncbi.nlm.nih.gov/pmc/articles/ PMC5946448/>. Accessed: May, 12, 2019. doi: 10.1186/ s13028-018-0382-8.

PELIZZARI, C. et al. Medium frequency neuromuscular electrical stimulation (russian) in dogs with induced muscle atrophy. Ciência Rural, v.38, p.738-742, 2008. Available from: <https://www. 
scielo.br/pdf/cr/v38n3/a22v38n3.pdf $>$. Accessed: May, 12, 2019. doi: 10.1590/S0103-84782008000300022.

PRYDIE, D; HEWIT, I. Practical physiotherapy for small animal practice. 1.ed. Chichester: John Wiley \& Sons, 2015. 292p.

SOUZA, S. F. et al. Rehabilitation in dogs submitted to knee arthroplasty. Ciência Rural, v.36, n.5, 2006. Available from: $<$ https://www.scielo.br/pdf/cr/v36n5/a17v36n5.pdf $>$. Accessed: May, 14, 2019. doi: 10.1590/S0103-84782006000500017.

SIMS, C. et al. Rehabilitation and physical therapy for the neurologic veterinary patient. Veterinary Clinics of North America. Small
Animal Practice, v.45, p.123-143, 2015. Available from: $<$ https:// pubmed.ncbi.nlm.nih.gov/25440754/>. Accessed: May, 12, 2019. doi: 10.1016/j.cvsm.2014.09.007.

SUTTON, A; WHITLOCK, D. Massage. In: MILliS, D.L.; LEVINE, D. Canine rehabilitation and physical therapy. 2ed. Philadelphia: Elsevier, 2014. Cap.27, p.464-483.

VINAYAK, A. et al. Effects of femur position on radiographic assessment of completeness of femoral head and neck excision in medium- to large breed dogs. American Journal Veterinary Research, v.67(1). p.64-69, 2006. Available from: <https:// pubmed.ncbi.nlm.nih.gov/16426213/>. Accessed: May, 16, 2019. doi: 10.2460/ajvr.67.1.64. 